(Jpn. J. Hosp. Pharm:

$\left(\begin{array}{c}\text { 料 } \\ 24(6) 729-736 \text { (1998) }\end{array}\right)$

\title{
薬剤性肺炎の最近の動向と問題点
}

\author{
森川正子 ${ }^{*} \dagger^{1}$, 佐藤数馬 $\dagger^{1}$, 村井容子 $\dagger^{2}$, 平良真奈子 $\dagger^{2}$, 赤川志のぶ $\dagger^{3}$ \\ 東京薬科大学薬学部総合医療薬学講座 $\dagger^{1}$, \\ 東京都多摩老人医療センター呼吸器内科 ${ }^{2}$ \\ 国立療養所東京病院内科 $\dagger^{3}$
}

\section{An Attitude and Problem of Drug-induced Pneumonitis}

\author{
MASAKO MORIKAWA $* \dagger^{1}$, KAZUMA SATOH $\dagger^{1}$, YOUKO MURAI $\dagger^{2}$, \\ MANAKO TAIRA $\dagger^{2}$ and SINOBU AKAGAWA $\dagger^{3}$ \\ School of Pharmacy, Tokyo University of Pharmacy and Life Science $\dagger^{1}$ \\ Internal Medecine, Tokyo Metropolitan Tama Geriatric Hospital $\dagger^{2}$ \\ Internal Medecine, National Tokyo Hospital $\dagger^{3}$
}

$\left(\begin{array}{l}\text { Received February 13, } 1998 \\ \text { Accepted June 2, } 1998\end{array}\right)$

In recent years, the number of drug-induced cases of pneumonitis have been reporled to increase. In this study, a literature-based investigation was performed to review the cases reported after Tomioka's study. Moreover, the reported cases in Tokyo Metropolitan Tama Geriatric Hospital, National Tokyo Hospital and Seire Hamamatu Hospital were also retrospectively reviewed.

1. Between July 1993 and December 1996,180 cases of drug-induced pneumonitis were reported in the domestic literatures. Twenty-one of which were related to antineoplastics or immunosuppressants ; while 49 cases were caused by antibiotics. Among the remaining 110 cases, interferon (s),herbal remedies and cold preparations constitued 34, 26, and 5 cases respectively. Within the 26 herbal remedy-induced cases, 21 of them were due to Shosaikoto. A whole variety of drugs including GCSF and an increased number of drugs were reported.

2. In the three hospitals, similar distributions of drug-induced pneumonitis cases were shown with the majority related to herbal remedies and interferon (s).

3. According to the reports in the literature and from the three hospital, the results of treatments and prognosis were related to the discontinuation of the suspected agents. Consequently, early detection and discontinuation of causative agents can improve the prognoses of drug-induced pneumonitis.

In order to detect drug-induced pneumonitis at an early stage, a database on the characteristics of the causative drugs should be systemically established and be readily available to health care professionals. Moreover, the early implementation of a centralized medication history system will facilitate the tracking of the causes of such drug-induced diseases.

Key words — drug-induced pneumonitis, herbal remedies, shosaikoto, interferon (s) 


\section{緒言}

医原性に引き起こされる呼吸器系疾患として は，薬剤投与による薬剤性肺炎と放射線照射に伴 う放射線肺炎が最も多いとされている ${ }^{1)}$ ここのう ち薬㘊性肺炎は，その発症機序により薬剤の細胞 毒性や組織傷害性によるもの (cytotoxic reaction) と免疫反応によるもの（allergic reaction）に大別 され，発症型により間質性肺炎，SLE型肺炎， 肺血管障害型肺炎に分類される ${ }^{2)}$ 。これらのうち 薬剤誘起性間質性肺炎については，これまで本邦 における1993年 6 月までの事例が近藤 ${ }^{3)}$ と富岡 ${ }^{4)}$ により集計され報告れているが近年，いくつかの 重篤な薬剤性間質性肺炎の発症が報告され, 臨床 上大きな問題となってきている ${ }^{5)}$.そこで, 薬剤 性肺炎の近年の発症動向とその問題点の新たな検 討が必要であると考え, 1993年 7 月以降本邦にお いて報告されている事例を文献検索・集計すると ともに, 東京都多摩老人医療センタ一, 国立療養 所東京病院および聖隷浜松病院において薬剤性肺 炎が疑われた事例について，レトロスペクティブ な検討を行った.

\section{実験材料・方法}

1. 1993年 7 月から1996年12月までの間に，本 邦において報告されている事例を文献検索した。 文献検索には, 医学中央雑誌の CD-ROM を使用 してキーワード検索（薬骫性肺炎，間質性肺炎， 報告のある起因薬剤名など）する方法と，日本胸 部疾患学会雑誌, 日本胸部臨床, 呼吸, 内科など の医学雑誌から直接収集する方法を用いた。二つ の検索方法によって得られた全事例のうち，原因 薬剤の明記されている報告例を重複のないように 注意して集計した。

\footnotetext{
$\dagger^{1}$ 東京都八王子市堀之内1432-1;1432-1, Horinouchi, Hachiouji, Tokyo 192-0392 Japan

$\dagger^{2}$ 東村山市青葉町1丁目7-1;7-1, Aobamachi 1-chome, Higashimurayama-shi, 189-0002 Japan

$\dagger^{3}$ 清瀬市竹丘3丁目1-1;1-1, Takeoka 3-chome, Kiyoseshi, 204-0023 Japan
}

2. 東京都多摩老人医療センター, 国立療養所 東京病院および聖隷浜松病院の医療記録より，薬 剤性肺炎の疑われた事例を抽出した。また，これ らの事例において, 薬戍性肺炎の鑑別・診断に必 要と考えられる情報の検索をレトロスペクティブ に行った。

3. 3 施設の事例および文献検索症例の中で原 因薬剤として報告例が多い薬郕または注目される 薬剤について, その特徵などの検討・解析を行っ た.

\section{結果}

\section{1. 薬剤性肺炎の起因薬剤として報告された薬} 剂

1993年 7 月から1996年12月までに薬剤性肺炎と して報告された事例は全部で180例あり，患者の 平均年齢は58.6歳（19-89藏）, 男女比は11：9 であった. 1980年から1989年までの10年間の薬剤 性肺炎の発症は, 近藤の報告によれば185例 ${ }^{3)}$ あったのに比べて，1990年から1993年 6 月までの 富岡の報告で174例4), 今回調査した1993年 7 月 から1996年12月までは180例と，80年代に比べて 90年代には報告例数が増加していることが明らか となった。

今回集計された事例において起因薬凨と考えら れる全薬剤名を Table 1 に, 各々の薬剤の起因割 合を Fig. 1 に示した. Fig. 1 には, 比較のため近 藤と富岡により報告された原因薬剤の起因割合も 作図して併記した。

80年代には，抗がん・免疫抑制薬93例 $(50 \%)$, 抗生物質 ·化学療法薬44例 (24\%), 金剂を主体 とする抗りウマチ薬30例（16\%）などが, 薬剤性 肺炎の原因薬㘊として多かったの比べて，90年代 には, 近藤がその他の薬物として分類した薬剤に よるものが多く，今回の調查でも全体の $61 \%(110$ 例）を占めていた，漢方薬の小柴胡湯，柴朴湯， 麦門冬場, 六君子湯, 半夏瀉心湯による発症が散 見されることが特に目をひき, 小柴胡湯などの漢 方薬 (26例：14\%) とインターフェロン (IFN,34 
Table 1. 文献検索による薬剤性肺炎原因薬剤一覧

(1993年7月〜1996年12月、全180例)

\begin{tabular}{|c|c|c|c|c|c|}
\hline 抗がん・免疫抑制菜 & & 21 & その他 & & 110 \\
\hline メトトレキセート & & 11 & インターフェロン & & 34 \\
\hline ブスルファン & & 3 & 萁方薬 & & 26 \\
\hline シスブラチン & & 2 & 小柴胡溜 & 17 & \\
\hline シタラビン & & 1 & 柴朴濡 & 3 & \\
\hline ラニムスチン & & 1 & 大柴胡濡, 㚆門灌, & & \\
\hline ヘプロマイシン & & 1 & 六君子晹 & & \\
\hline パクリタキセル & & 1 & 半夏蔦心清， & & \\
\hline テカフール・ウラシル & & 1 & 片仔店, その他 & 各1 & \\
\hline 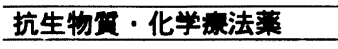 & & 49 & 抗リウマチ菜 & & 11 \\
\hline 抗䊅核菲 & & 14 & 金彆郕 & 6 & \\
\hline エタンブトール & 6 & & ブシラミン & 3 & \\
\hline ストレプトマイシン & 5 & & オーラノフィン & 2 & \\
\hline イソニアジド & 2 & & 消炎·锤斯菜 & & 10 \\
\hline リファンピシン & 1 & & 棇合葽回菜 & & 5 \\
\hline ミノサイクリン & & 12 & 抗うつ莱 & & 3 \\
\hline セフェム系 & & 7 & アモキセピン & 1 & \\
\hline セフォチアム & 1 & & マプロチニン & 1 & \\
\hline セファドキシル & 1 & & 抗样神菲 & 1 & \\
\hline セファレキシン & 1 & & 抗けいれん来 & & 3 \\
\hline セフメタソール & 1 & & カルバマゼピン & 1 & \\
\hline フロモキセフ & 1 & & その他 & 2 & \\
\hline その他 & 2 & & アミオダロン & & 2 \\
\hline ニューキノロン莱 & & 4 & チアマソール & & 2 \\
\hline オフロキサシン & 2 & & $\beta$-刺湤菜 & & 2 \\
\hline その他 & 2 & & エフェドリン & 1 & \\
\hline イミペネム・シラスタチ & ヒン & 2 & プロカテロール & 1 & \\
\hline ロキスロマイシン & & 1 & エポエチン、G-CSF & & \\
\hline その他 & & 9 & $\begin{array}{l}\text { プレドニソロン、 } \mathrm{BC} \\
\text { コルヒチン、シロス } \\
\text { トリメタジシン、 } \\
\text { ナファモスタット. } \\
\text { シンナー、エレース }\end{array}$ & $\begin{array}{l}\text { ソール } \\
\text { エジピン } \\
\text { ラコート }\end{array}$ & 以上各 1 \\
\hline
\end{tabular}

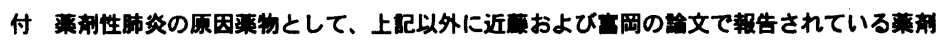
抗が・兔度抑制菜-フフレオマイシン、シクロホスファミト、ニトロソウレア、アザチオブリン、 マイトマイシンC、ドキソルビシン、ビンデシン、ビンクリスチン、エトボシト

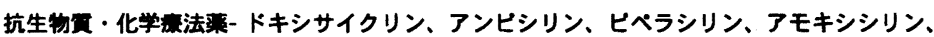
エノキサシン、ノルフロキサシン、アムホテリシンB、クリンタマイシン、ホスホマイシン、 ニトロフラントイン その他- Dーペニシラミン、ジフェニールヒタントイン、パルプロ破、フェノパルビタール、 アセトアミノフェン、ナブロキセン、セラベブチターせ、プロピルチォウラシル、 アロブリノール、フロボキセート、エトキシスクレロール、トリクロルチアジト、エナラブリル、 サラソビリン、アブリンジン、ホミノベン、チオブロニン、ジクロフェナミド、ワルファリン、 スルファサラジン、Lーシステイン、 $\alpha$-メチルドパ
}

例：19\%）による発症が増加傾向にあることが明 らかとなった。さらに，G-CSFなどの新薬が， 原因薬剤に含まれていることも新しい傾向として
認められた。

2. 東京都多摩老人医療センター, 国立療養所東 京病院, 聖隷浜松病院での事例 

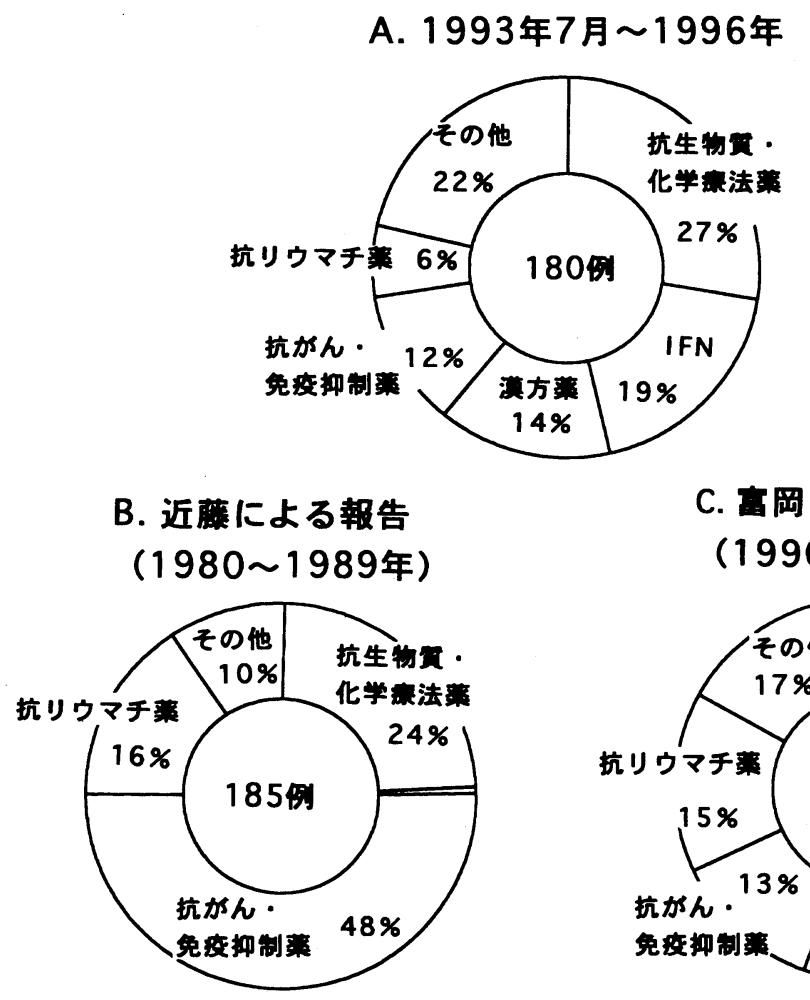

C. 亩岡による報告

(1990〜1993年6月)

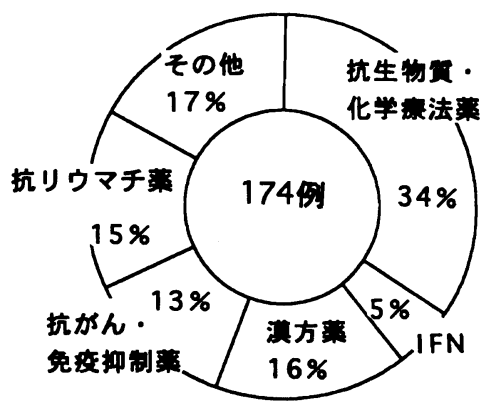

Fig. 1. 薬殽性肺炎の原因薬剤

1987年から1996年の10年間に, 東京都多摩老人 医療センターにおいて薬剤性肺炎の疑われた事例 は 4 事例, 国立療養所東京病院においては11事 例, 聖隷浜松病院においては 6 事例, 計21事例で あった。患者の平均年齢は67.1歳（45～84歳）, 男女比は $4: 3$ であった。起因薬剤の内訳は, 抗 がん剤 4 例, 抗生物質・化学療法薬 2 例（ミノサ イクリン（MINO）1，ストレプトマイシン 1)， その他15例（小柴胡湯 $4, \operatorname{IFN} 3$, 柴朴湯 2 , 柴 苓湯 2 , 辛夷清肺湯 1 , オムニパーク 1 , ミオ ゾール 1 ，ブシラミン 1 ) であった.

近年, 特に注目されている小柴胡湯による発症 例と小柴胡湯と IFN 併用による発症例の典型的 な事例を以下に示す。

1 ）小柴胡湯による発症例：53歳男性

主訴：呼吸困難

既往歴：2歳の時，小児期肺炎。16歳時，扁桃
腺肥大手術。10年以上前，マニラで重篤な発熱と 下痢 ( 3 日間).

生活歴：4～5 年前より寒冷じん麻疹発症. 抗 生剤（不明）でアレルギー歴あり。タバコ30本/ 日 (17歳から52歳).

現病歴：1994年春,肝機能障害を指摘され,1995 年 7 月 21 日小柴胡湯の内服を開始する。 8 月16日 発熱，その後持続. 労作時に呼吸困難出現. 胸部 $\mathrm{X}$ 線上にびまん性陰影が見られ，8月22日某院入 院. 小柴胡湯の投薬中止. セフメタゾールナトリ ウム, ピペラシリンナトリウム, 硫酸アミカシン などの抗生剤の投与を次々に受け, 次第に症状改 善.小柴胡湯が 8 月28日に再開された。胸部 X 線上陰影が完全に消失しないまま 9 月 6 日退 院. 10月16日より $38^{\circ} \mathrm{C}$ 台の発熱が持続したた め, 10月19日紹介入院となる.

入院時検査所見: pH 7.424, $\mathrm{PaCO}_{2} 34.5$, 
$\mathrm{PaO}_{2}$ 81.2. 胸部 $\mathrm{X}$ 線にて両肺にスリガラス様陰 影. 胸部 CT にて両肺に広範囲にスリガラス様陰 影. 気管支肺胞洗浄液（BAL）に総細胞数 (54.4 $\left.\times 10^{6}\right)$ およびリンパ球比率の増加がみられ, 経 気管支肺生検（TBLB）にて胞隔炎の所見あり。 小柴胡湯に対するリンパ球刺激試験（DLST）は, 末梢血・BAL とも陰性.

経過：小柴胡湯再投与による小柴胡湯誘因性間 質性肺炎を疑い, 小柴胡湯の投与を中止し経過観 察のみとしたところ, 肺機能および自覚症状の改 善が認められた。

2 ）小柴胡湯と IFN の併用による発症例：66 歳女性

主訴：乾性咳嗽, 労作時呼吸困難

既往歴：35歳時，子宮筋腫手術（輸血十)．45 歳時, 高血压.

生活歴：干物に対するアレルギー歴あり.

現病歴：慢性活動性肝炎に対して，1992年 2 月 3 日から 3 月 1 日まで IFN $\alpha-2$ a 9 MU 連日投 与. 3 月 2 日から IFN $\alpha-2 \mathrm{a} 6 \mathrm{MU}$ 週 3 回隔日投 与. 5 月 6 日労作時に呼吸困難出現. 5 月12日か ら乾性咳嗽と発熱出現．5月15日入院となる。

入院時検查所見：チアノーゼあり。両側下肺野 にファインクラックルを聴取. WBC 3,600, GOT 139, GPT 77, LDH 520, $\mathrm{PaCO}_{2}$ 37.5, $\mathrm{PaO}_{2} 52.5, \mathrm{RA} 2+$, RAPA $\times 640$, 胸部 X 線に て両側下肺野, 特に右下に粒状網状影を確認。

経過：入院から 3 日間ステロイドパルス療法 （メチルプレドニゾロン）を受ける，5月18日プ レドニゾロン（PSL） $40 \mathrm{mg}$ /日内服開始. 6 月11 日より PSLを漸減し順調に症状改善. 7 月 4 日 （第51病日目）軽快により退院. 末梢血 DLST は 小柴胡湯と IFN とも陰性.

\section{3. 薬剂性肺炎の起因薬剤となる薬剤の特徵}

今回, 文献検索によって得られた報告事例と実 際に 3 施設で認められた発症事例について, 患者 の平均年齢, 男女比, 原因薬剤の投与開始から発 症までの日数, 主訴, 基礎疾患, 画像所見, 治療 内容などを収集し，原因薬剤別に肺炎の特徴を検
討した（Table 2).いずれの薬剤による肺炎で も主訴としては, 呼吸困難, 発熱, 咳嗽が高率で 認められた。 また多くの事例で胸部 X 線所見上 にびまん性陰影が認められた。しかし，薬剤の投 与開始から発症までの日数（最短, 最長および平 均日数), DLST に対する反応性および予後につ いては薬剤間で相違が認められた。特に発症まで の日数が短いものとして G-CSF, MINO が挙げら れること，また発症までの日数に開きのあるもの として IFN, 漢方薬, 抗リウマチ薬, 抗がん剤が 認められた。

小柴胡湯および IFN の単独使用による発症例 および併用による発症例で症状の比較を行った結 果を Table 3 に示す. 小柴胡湯単独使用により発 症した症例は21例あり, 患者の平均年齢は 66.3 歳, 男女比は12：9であった。投与開始から発症 までの平均日数121日（最短12日, 最長 3 年 2 力 月）であり, 主訴としては呼吸困難や発熱が多か った. 基礎疾患としては C 型肝炎などの肝機能 障害が半数以上の患者に認められた。画像所見と しては両側下肺野を中心とした粒状や網状の陰影 が多くの事例で認められた。検查所見では CRP, ESR およびLDHの上昇が多くの事例で認 められ, 血液ガス中の平均 $\mathrm{PaO}_{2}$ 值は55.7であっ た. BALでは総細胞数およびリンパ球分画の増 加が, TBLB では胞隔炎が多くの事例で認められ た. DLST 陽性率は67\%と高值を示していた，先 に示した症例 1 のように投薬中止のみで自然軽快 傾向を示すものが21例の事例中12例あり， 1 例を 除いては予後良好であった。

IFN 単独使用により肺炎を発症した症例は15例 あり, 患者の平均年齢は56.1歳, 男女比は $9: 6$ であった. 投与開始から発症までの平均日数は 158日（最短13日, 最長 2 年 6 カ月), 主訴として は呼吸困難や咳嗽が多く, 患者の基礎疾患はその ほとんどが C 型肝炎であった。画像所見では両 側の中・下肺野を中心とした斑状影や網状影が多 く認められた。検査所見では，CRR， ESR およ びLDHの上昇が多くの事例で認められ, 血液ガ 
Table 2. 原因薬剂別の薬剂性肺炎の特徵

\begin{tabular}{|c|c|c|c|c|c|c|c|c|c|c|c|}
\hline & \multirow[b]{2}{*}{ 男女比 } & \multirow{2}{*}{$\begin{array}{l}\text { 平均 } \\
\text { 年鉿 }\end{array}$} & \multirow{2}{*}{$\begin{array}{l}\text { 発掟までの } \\
\text { 平均日数 } \\
\text { (最短-最長) }\end{array}$} & \multirow{2}{*}{ 主訴 } & \multirow{2}{*}{ 胸部X線所胃 } & \multicolumn{2}{|c|}{ DLST所見 } & \multicolumn{2}{|l|}{ 治療 } & \multicolumn{2}{|l|}{ 予後 } \\
\hline & & & & & & 陯性 & 險性 & 中止のみ & 又绪使用 & 船快 & 死亡 \\
\hline IFN & 22:15 & 57.8 & $\begin{array}{c}116 \\
(2-912)\end{array}$ & $\begin{array}{l}\text { 呼吸困難 } \\
\text { 咳噒 }\end{array}$ & $\begin{array}{l}\text { びまん性陰影 } \\
\text { 間䓄性陰影 }\end{array}$ & $3 / 22$ & $19 / 22$ & $6 / 37$ & $31 / 37$ & $31 / 37$ & $6 / 37$ \\
\hline 漠方菲 & $16: 19$ & 65.4 & $\begin{array}{c}109 \\
(11-1155)\end{array}$ & $\begin{array}{l}\text { 呼吸困難 } \\
\text { 発熱 }\end{array}$ & $\begin{array}{l}\text { 粒状網状影 } \\
\text { びまん性隍影 }\end{array}$ & $20 / 31$ & $11 / 31$ & $12 / 29$ & $17 / 29$ & $34 / 35$ & $1 / 35$ \\
\hline 抗結校蓝 & $10: 5$ & 67.0 & $\begin{array}{c}55 \\
(16-90)\end{array}$ & $\begin{array}{l}\text { 血痰 } \\
\text { 胸部異常陰影 } \\
\text { の精查 }\end{array}$ & 粒状影 & $4 / 8$ & $4 / 8$ & $3 / 9$ & $6 / 9$ & $14 / 15$ & $1 / 15$ \\
\hline 抗リウマチ㹂 & $4: 8$ & 53.4 & $\begin{array}{c}387 \\
(25-1190)\end{array}$ & $\begin{array}{l}\text { 呼吸困㘗 } \\
\text { 咳 }\end{array}$ & $\begin{array}{l}\text { びまん性陰影 } \\
\text { スリガラス滕陰影 }\end{array}$ & $4 / 7$ & $3 / 7$ & - & $12 / 12$ & $10 / 12$ & $2 / 12$ \\
\hline MINO & $5: 8$ & 54.6 & $\begin{array}{c}9 \\
(4-15)\end{array}$ & $\begin{array}{l}\text { 呼吸困難 } \\
\text { 咳濑 }\end{array}$ & $\begin{array}{l}\text { びまん性狯影 } \\
\text { スリガラス溙陰影 }\end{array}$ & $1 / 12$ & $11 / 12$ & $3 / 12$ & $9 / 12$ & $13 / 13$ & - \\
\hline 坑癌剂 & $11: 11$ & 66.5 & $\begin{array}{c}123 \\
(3-600)\end{array}$ & $\begin{array}{l}\text { 発熱 } \\
\text { 呼吸困嚾 }\end{array}$ & $\begin{array}{l}\text { 間買性唅影 } \\
\text { びまん性陰影 }\end{array}$ & $6 / 6$ & - & $4 / 19$ & $15 / 19$ & $17 / 22$ & $5 / 22$ \\
\hline 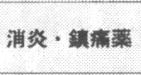 & $3: 7$ & 53.7 & $\begin{array}{c}11 \\
(1-15)\end{array}$ & 呼吸困孉 & 䊉状影 & $3 / 6$ & $3 / 6$ & $7 / 10$ & $3 / 10$ & $7 / 10$ & $3 / 10$ \\
\hline 総合感品垍 & $2: 3$ & 50.4 & $\begin{array}{c}7 \\
(2-10)\end{array}$ & $\begin{array}{l}\text { 発熱 } \\
\text { 咳乘 }\end{array}$ & びまん性陰影 & $5 / 5$ & - & $2 / 4$ & $2 / 4$ & $5 / 5$ & - \\
\hline G-CSF & $1: 2$ & 65.7 & $\begin{array}{c}4 \\
(2-6)\end{array}$ & 不明 & $\begin{array}{l}\text { びまん性險影 } \\
\text { 龬状影 }\end{array}$ & \multicolumn{2}{|c|}{ 不明 } & $1 / 3$ & $2 / 3$ & $3 / 3$ & - \\
\hline
\end{tabular}

ス骩使用：ステロイド骩使用

Table 3. 小柴胡湯・インターフェロン単独例および併用例薬剂性肺炎の特徵

\begin{tabular}{|c|c|c|c|}
\hline & 小柴胡湯使用例 & IFN使用例 & 小柴胡湯，IFN 併用例 \\
\hline 男女比 & $12: 9$ & $9: 6$ & $13: 9$ \\
\hline 平均年齽 & $66.3(53-78)$ & $56.1(33-75)$ & $59.0(41-68)$ \\
\hline $\begin{array}{l}\text { 発应までの平均日数 } \\
\text { （最短- 最長） }\end{array}$ & $\begin{array}{l}121 \\
(12-1155)\end{array}$ & $\begin{array}{l}158 \\
(13-912)\end{array}$ & $\begin{array}{l}\text { 併用後56 } \\
(2-210)\end{array}$ \\
\hline 主訴 & 呼吸困難, 発熱、咳濑 & 呼吸困嚄, 咳濑、発熱 & 呼吸困難, 咳濑、発熱 \\
\hline 基磷疾患 & $\begin{array}{l}\text { 肝機能障害, C型慢性肝炎, } \\
\text { 慢性肝炎 }\end{array}$ & C型慢性肝炎, 肝機能障富 & C型慢性肝炎, 肝機能障堙 \\
\hline 胸部X線所見 & 網状影、粒状影、スリガラス菉猿影 & 斑状影，網状影 & びまん性間質性陰影, 網状影 \\
\hline 臨床検查所見 & CRP、ESR、LDHの增加 & CRP、ESR、LDHの壃加 & CRP、ESR、LDHの増加 \\
\hline 平均 $\mathrm{PaO}_{2}$ 值 & 55.7 & 59.7 & 55.5 \\
\hline $\begin{array}{l}\text { BAL所見 } \\
\text { (気管支肺胞洗浄) }\end{array}$ & $\begin{array}{l}\text { 総細胞数の増加、 } \\
\text { リンパ球分画の增加 }\end{array}$ & リンパ球分画の增加 & $\begin{array}{l}\text { 総細胞数の増加、 } \\
\text { リンパ球分画の増加 }\end{array}$ \\
\hline $\begin{array}{l}\text { TBLB所見 } \\
\text { （経気管支肺生検） }\end{array}$ & 胞隔炎 & 好酸球漫澗, 胞隔资 & 胞隔炎 \\
\hline \multirow{2}{*}{ 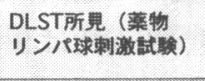 } & 䠦珄 & 隆性 & 陰性 \\
\hline & $14 / 21$ & $4 / 6$ & $16 / 17$ \\
\hline \multirow{2}{*}{ 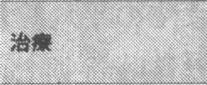 } & 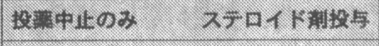 & 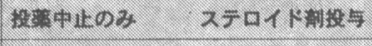 & 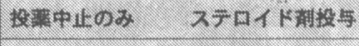 \\
\hline & $12 / 21$ & $14 / 15$ & $18 / 22$ \\
\hline \multirow{2}{*}{ 予㣫 } & 整快 & 死亡 & 死亡 \\
\hline & $20 / 21$ & $14 / 15$ & $17 / 22$ \\
\hline
\end{tabular}

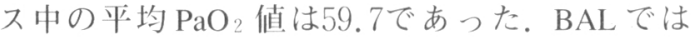
リンパ球分画の増加が, TBLBでは肺胞壁の肥厚
や胞隔炎が多くの事例で認められた。DLST 陽性 率は33\%であった。治療は15例の事例中14例でス 
テロイド剤が使用され，1例を除いては予後良好 であった。

IFN と小柴胡湯の併用により肺炎を発症した事 例は全部で22例あり, 患者の平均年齢は59歳, 男 女比は13：9であった。併用の形式およびその例 数, 両剤併用から発症までの平均日数は, 小柴胡 湯先行投与による発症例は17例で, 両剤併用開始 から発症までの平均日数は58日（最短 2 日, 最長 210日）であった。同時併用による発症例は 3 例 で, 発症までの平均日数133日（最短 40 日, 最長 180日）であった。 IFN 先行投与による発症例は 2 例で, 両剤併用開始から発症までの平均日数は 17.5日（最短14日，最長21日）であった。このな かには， 2 年間小柴胡湯が単独投与されていた事 例で, IFN 併用開始からわずか 2 日目に肺炎を発 症した事例があった。併用による発症例の主訴， 基礎疾患，検查所見，TBLB 所見は，それぞれの 単独使用発症例とほとんど同じであった。併用に よる発症事例の画像所見では, 両側の中・下肺野 を中心としたびまん性間質性陰影や網状影が多く の事例で認められた. 血液ガスの中の平均 $\mathrm{PaO}_{2}$ 值は55.5であった. 少数の例において肺機能検查 が施行されており，これによって拘束性障害が認 められた. BALでは総細胞数およびリンパ球分 画の増加が認められた. DLST 陽性率は $6 \%$ とそ れぞれの薬剤単独使用による発症事例よりも低值 であった。これらの治療には, 先に示した症例 2 のようにステロイド剤の使用が22例中18例で行わ れた。両䇕併用例と IFN 単独使用例の比較で は, 併用例の方が，ステロイド剤漸減中に症状の 再燃が認められたり，22例中 5 例に死亡例が認め られるなど，治療に難渋する傾向が認められた。 特に, 肺炎, 特発性肺線維症, 肺気腫など肺合併 症を有した患者では 8 例中 4 例が死亡し, ステロ イド治療に抵抗性で重症化しやすいことが認めら れた。

\section{考察}

臨床に用いられる薬髀量の増加や新薬の開発に
よる薬剤の種類の増加により，薬凨性肺炎は，年 とともに発症数・種類ともに増加傾向にあり，そ の発症形態も複雑になりつつある ${ }^{5)}$.

今回の検討においても，80年代と 90 年代の比較 ではそれぞれの時代背景を反映して，肺炎を誘起 したと考えられる薬剤に相違が認められている (Fig. 1 の比較). 80年代と90年代では, 漢方薬が

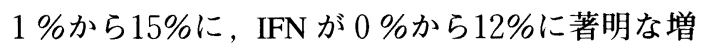
加をしたのに対して, 抗がん剤と免疫抑制薬が著 明に減少 $(49 \%$ から $12 \%)$ したことが特徴的であ る. 抗がん剤と免疫抑制薬による事例が90年代に 著しく減少したのは, 副作用の少ない有効な抗が ん浏の開発によりブレオマイシンなどの肺障害を 起こし易い抗がん剤の使用頻度が減少したこと や, 薬剤性肺炎の可能性が念頭に置かれて注意深 く治療が行われるようになったことによるものと 考えられる.

佐藤らは, 平成 2 年 1 月から平成 8 年 1 月まで に全国の医療施設から製薬会社に副作用報告書が 提出されたもののうち, 小柴胡湯による薬剤性肺 炎と判定された94例の事例について, 副作用報告 書を基に検討を加えている ${ }^{6)}$. この94例の事例の うち72例は小柴胡湯単独による薬剤性肺炎と判定 されており, 小柴胡湯により薬剤性肺炎が発症す る可能性が高いことが示されている. また小柴胡 湯により肺炎が発症した事例は, 小柴胡湯の投与 中止とステロイド剤の投与により64例 (88.9\%) が症状の改善を示したが, 残りの 8 例 (11.1\%) はそれらの治療が奏功せずに不帰の転機をとった とされている.これらの報告は, 漫然とした小柴 胡湯の投与（小柴胡湯を含む一般市販薬の使用も 含め) は, なされてはいけないことを示唆してい る.

最近，近藤がその報告の中で「その他の薬殽」

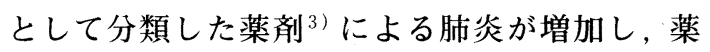
剤性肺炎の原因薬剤の多様化が認められている. なかでも小柴胡湯などのいくつかの漢方薬や IFN による薬剤性肺炎の増加が著明であり，1990年か ら1993年 6 月までの富岡の報告ではこれらの薬剤 
よる発症は37例であり，1993年 7 月から1996年12 月までの今回の調査で60例に増加していた．この 原因としては，1992年に IFN が C 型肝炎に保険 適用され使用頻度が増加したこと, 漢方薬との併 用が増加したことが挙げられる。今回の調査症例 のなかには，IFN 投与中の患者が市販の小柴胡湯 を自己購入服用した事例も含まれていた。この事 例は，病院からの処方薬の薬歴管理だけでなく， OTCを含めた薬歴管理の必要を強く示唆するも のである.

今回, 薬剤性肺炎の発症を判定する指標として DLSTの検討を行った。薬剤性肺炎発症例の DLST の陽性率は, 小柴胡湯単独使用事例では $67 \%$, IFN 単独使用事例では33\%，IFN・小柴胡 湯併用事例では $6 \%$ あった。このような DLST の陽性率の差が何によるかは，今回明らかにする ことはできなかったが，それぞれの病状の差や DLST 検查がステロイド剤の使用下にされた例も 多くその影響が考えられる.今回の検討で DLST が陰性か陽性かのみで，その薬剤が薬剤性肺炎の 原因かを判断することは問題があることが明らか になった。

現在, 薬剤性肺炎の診断は, 初期症状, 画像所 見, 生化学検查, 血液ガス, BAL所見, TBLB 所見, DLST 所見などにより総合に下されてい る. 薬剤性肺炎を誘起する危険性の高い薬物の投 与前には, 必ず肺の検査（画像所見など）を行 い, 既存の肺疾患の有無を確認し，もし障害があ る場合は投与を回避するか，投与する場合には慎 重に経過を観察する必要がある。また，障害がな くとも投与中には肺の定期検查を行うべきであ り, 薬剤性肺炎の発症が疑われる場合には速やか に投薬を中止し，早期治療に努めなければならな いと考える．原因薬物の再投与は肺炎を再燃させ ることが多く，これは大きな危険を伴っている が，現時点で原因薬剤同定の最も確実な手段とさ れている。.また，症例 1 のように小柴胡湯などの 漢方薬による発症事例では, 発症までに長い時間
を要することが，原因の判定の究明を困難にして いる．これらのことを考慮すると, 今後原因薬凨 を速やかに同定するためには，より特異性の高い 検査法が早期に確立され臨床応用されることが強 く望まれる.

新薬の開発や治療法の変化によって, 今後も薬 鼡性肺炎を引き起こす薬剤数は増加し，肺炎の症 状も多様化するものと考えられる。薬片性肺炎の 重症例では死が避けられないこともあるため，原

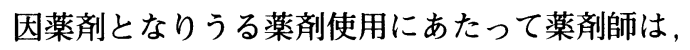
薬剤性肺炎の早期発見・治療に最善を尽くすだけ でなく，発症予防のために最大の努力を払わなけ ればならない。また，肺炎の原因薬凬について常 に文献収集と情報の整理に努め, その内容を迅速 に医師・患者に提供する義務を果たさなければな らない. また, 薬片誘起性疾恵の原因追求を容易 にするために，患者のすべての薬歴を一括管理す るシステムが一日も早く構築されるよう最大の努 力を果たさなければならない。

最後に，今回の我々の調查において市販の総合 胃薬を服用して薬剤性肺炎を発症した事例が 5 例 あったこと，またアセトアミノフェン服用によっ て肺炎が発症したという報告7)があったことか ら, 安易な薬の販売・服用には大きな警鐘が鳴ら されるべきであると考える.

\section{引用文献}

1) “新臨床内科学”, 第6版, 高久史麿, 尾形说郎監 修, 医学書院, 東京, 1993, pp 159-159.

2) W.J.Fulkerson Jr., J,P.Gockeman, "In pulmanary disease and diorders", 2 th ed., A.P. Fishmaneds., MaGraw-Hill Inc., New York, 1988, pp 793-811.

3) 近藤有好, 呼吸, 10 (5), 594-603 (1991).

4) 富岡洋海, 綜合臨床, 42 (9), 2701-2706 (1993).

5）太田健，星野恵津夫，内科， 77 (4)，698-702 (1996).

6) 佐藤篤彦, 豊島幹生 5 , 日本胸部疾患雑誌, 35 (4), 391-395 (1997).

7）赤松祥子, 日本胸部疾患雑誌, 35 (10), 974-979 (1997). 